\title{
Taking Care of Children With Cancer: Evaluation of the Caregivers' Burden and Quality of Life
}

\author{
Elizete Aparecida Rubira do Espírito Santo ${ }^{1}$ \\ Maria Aparecida Munhoz Gaíva² \\ Mariano Martinez Espinosa ${ }^{3}$ \\ Dulce Aparecida Barbosa ${ }^{4}$ \\ Angélica Gonçalves Silva Belasco ${ }^{4}$
}

Introduction: Cancer is a disease of high incidence among children and the patients need a caregiver during the treatment. Aim: to evaluate: the burden of care and quality of life (QOL) of caregivers of children/adolescents with cancer during chemotherapy treatment and relate them to each other and to the socio-demographic data and the presence and degree of signs of depression, Method: It is a cross-sectional study, with 32 caregivers. Socio-demographic, care burden (Caregiver Burden Scale) and QOL data (SF-36) were collected. Results: 87.5\% of the caregivers were mothers, total score of burden $1.92 \pm 0.09$ and most compromised score of the SF-36: emotional aspects (59.3), vitality (60.0), pain (60.9). There was a significant correlation between burden and mental health and vitality. Conclusion: Caregivers presented care burden and compromised aspects of QOL and possibly need interventions that will promote social and emotional wellbeing to reduce the burden, improve the quality of life QOL and consequently deliver better care.

Descriptors: Caregivers; Quality of Life; Drug Therapy; Child Care.

\footnotetext{
${ }^{1}$ RN, M.Sc. in Health and Environment. Assistant Professor, Universidade Federal do Mato Grosso, MT, Brazil. E-mail: elrubira@terra.com.br.

2 RN, Ph.D. in Public Health Nursing. Adjunct Professor, Universidade Federal do Mato Grosso, MT, Brazil. E-mail: mamgaiva@yahoo.com.br.

${ }_{3}$ Statistician, Post-doctor in Reliability. Adjunct Professor, Universidade Federal do Mato Grosso, MT, Brazil. E-mail marianom@cpd.ufmt.br.

${ }^{4}$ RN, Post-doctor in Nefrology. Adjunct Professor, Universidade Federal de São Paulo, SP, Brazil. E-mail: Dulce dulce@denf.epm.br, Angélica abelasco@denf.epm.br.
}

Corresponding Author:

Elizete Aparecida Rubira do Espírito Santo

Universidade Federal de Mato Grosso. Faculdade de Enfermagem

Departamento de Enfermagem

Av. Fernando Correa da Costa, 2.367

Bairro: Boa Esperança

CEP: 78060-900 Cuiabá, MT, Brasil

E-mail: earubira@gmail.com 


\section{Cuidando da criança com câncer: avaliação da sobrecarga e qualidade de vida dos cuidadores}

Câncer é doença de alta incidência entre crianças, e os portadores necessitam de cuidador durante o tratamento. O objetivo deste estudo foi avaliar a sobrecarga de cuidado e qualidade de vida (QV) dos cuidadores de crianças/adolescentes, portadoras de câncer, durante o tratamento quimioterápico, e relacioná-las entre si e aos dados sociodemográficos, e a presença e grau de sinais de depressão. Trata-se de estudo transversal, com 32 cuidadores. Coletados dados sociodemográficos, sobrecarga de cuidado (caregiver burden scale) e de QV, através do SF-36. Os resultados mostraram que $87,5 \%$ dos cuidadores eram mães, idade média de 35 anos, escore geral de sobrecarga $1,92 \pm 0,09$ e escores do SF-36 mais comprometidos: aspectos emocionais $(59,3)$, vitalidade $(60,0)$ e dor $(60,9)$. Houve correlação significativa entre sobrecarga, saúde mental e vitalidade. Conclui-se que os cuidadores apresentaram sobrecarga de cuidado e aspectos de QV comprometidos e, possivelmente, necessitam de intervenções que promovam bem-estar físico, social e emocional, para diminuir a sobrecarga, melhorar a QV e, consequentemente, prestar melhor assistência.

Descritores: Cuidadores; Qualidade de Vida; Quimioterapia; Cuidado da Criança.

\section{Cuidando del niño con cáncer: evaluación de la sobrecarga y calidad de vida de los cuidadores}

El cáncer es una enfermedad de alta incidencia entre niños, los que necesitan de un cuidador durante el tratamiento. Se tuvo por objetivo evaluar la sobrecarga de cuidado y la calidad de vida (CV) de los cuidadores de niños/adolescentes portadores de cáncer durante el tratamiento quimioterápico, y relacionarlas entre sí y a los datos sociodemográficos, y a la presencia y grado de señales de depresión. Se trata de un estudio transversal, con 32 cuidadores. Fueron recolectados datos sociodemográficos, sobrecarga de cuidado (Caregiver Burden Scale) y de CV a través del SF-36. El 87,5\% de los cuidadores eran madres, la edad promedio fue 35 años, el puntaje general de sobrecarga fue 1,92 $\pm 0,09$ y los puntajes del SF-36 más comprometidos fueron: aspectos emocionales $(59,3)$, vitalidad $(60,0)$ y dolor $(60,9)$. Se encontró correlación significativa entre sobrecarga, salud mental y vitalidad. Concluimos que los cuidadores presentaron sobrecarga de cuidado y aspectos de CV comprometidos y posiblemente necesitan de intervenciones que promuevan el bienestar físico, el social y el emocional, para disminuir la sobrecarga y mejorar la CV, y así consecuentemente mejorar la asistencia.

Descriptores: Cuidadores; Calidad de Vida; Quimioterapia; Cuidado del Niño.

\section{Introduction}

The appearance of a disease in a family member entails countless changes in the family structure. When the disease is cancer, the situation gets worse, as this is a stigmatized illness the population fears, due to the suffering it causes to patients and relatives. The cancer diagnosis affects patients, significant others and relatives they have contact with, mainly when countless care acts are needed(1). Among chronic childhood illnesses, cancer stands out due to its high incidence rate and repercussions in children and families' lives ${ }^{(2)}$.

In general, different professionals focus on the sick patients, while relatives/caregivers are seen as helpers in the care process, without being acknowledged as people who are going through a painful process and need help and support(1). In the last decade, teams who deliver care to children with cancer have made efforts 
to understand the diagnosis and cancer treatment in children as a psychologically traumatic event for the parents $^{(3)}$. Other studies related to chronic illnesses, including cancer, have tried to clarify the effects of the illness on the life of people living with the patient, mainly caregivers, through scales that assess quality of life and measure burden and depression, among other parameters $^{(3-5)}$.

The caregiver-related qualitative aspects that have been most researched on recently are emotional and social aspects and the impact of care, stress and depression. The strong impact caregivers experience and family disorganization are similar findings in most studies on the theme. These studies demonstrate that caregivers manage to acknowledge the fundamental role they play in care delivery to a close relative, mainly their child(6).

New quantitative studies, using scales to measure quality of life, care burden, fatigue, depression, anxiety, mood, body image, social inclusion, among others, also have been increasingly accomplished involving caregivers of patients with chronic illnesses ${ }^{(7-10)}$.

These different ways of approaching caregivers can produce fundamental information to understand them and support health professionals to put in practice guided and effective actions, which can minimize the impact of the care delivered to family members with chronic illnesses ${ }^{(5)}$.

As caregivers assume the responsibility for care, this study aimed to assess the burden, quality of life and presence of depression in caregivers of children with cancer during chemotherapy.

\section{Method}

Approval for the research project was obtained from the Institutitonal Review Board of Universidade Federal de São Paulo (UNIFESP), opinion No CEP 0555/07. Caregivers in the sample were invited to participate in the research during their stay at the chemotherapy sector. After their acceptance, they received further information about the study goals and signed the free and informed consent term. The study design was cross-sectional and was accomplished at the Pediatric Oncology Service (Ágape) of Hospital do Câncer de Mato Grosso. The study population comprised caregivers of children and adolescents with cancer, with a confirmed diagnosis through the anatomopathological exam or myelogram and under chemotherapy for at least two months. Caregivers were considered as family members, older than 18 , who took care of the patient most of the time, lived in the same house and agreed to participate in the study.

The sample $(n=32)$ was obtained through the stratified probabilistic sampling method, proportional to the mean number of children and adolescents attended during the six months before the research. Data were collected in March and April 2008. The time spent for each interview ranged between 20 and 40 minutes. Through an individual interview and in a reserved room at the child chemotherapy unit, the following data were collected: social and demographic data; care overload through the Caregiver Burden Scale (CBS), which comprises 22 questions and is subdivided in five dimensions: general tension, isolation, disappointment, emotional involvement and environment, with partial and total scores ranging from 1 (no burden) to 4 (worst burden) ${ }^{(8)}$; quality of life assessment data through the Medical Outcomes Study 36 - Item Short-Form Health Survey, with 36 items grouped in eight dimensions: physical role functioning, physical functioning, bodily pain, general health perception, vitality, soial role functioning, emotional role functioning and mental health ${ }^{(11)}$ and scores ranging from 0 (pior estado) to 100 (melhor estado).

Also, Beck's Depression Inventory (BDI) was applied to assess the presence and degree of caregivers' depression signs, comprising 21 items, including symptoms and attitudes. Answers range between 0 (absence of symptoms) and 3 (enhanced depression symptoms). Items relate to sadness, pessimism, feeling of failure, lack of satisfaction, feeling of guilt, feeling of punishment, self-depreciation, self-accusations, suicidal ideas, crying crises, irritability, social retraction, indecision, distorted body image, inhibition to work, sleep disorder, fatigue, loss of appetite, weight loss, somatic concern, decreased libido. Various cut-off scores have been proposed to distinguish among depression levels but, for non-diagnostic samples, scores above 15 are recommended for dysphoria and above 20 for depression ${ }^{(9)}$.

To characterize the sample data, descriptive and inferential analyses were performed. The correlation between CBS and SF-36 dimensions was verified through Pearson's correlation coefficient. Multiple linear regression analysis was performed for total CBS (dependent variable), in function of independent sociodemographic variables, SF-36 dimensions and BDI. Variables with significance levels $p<0.05$ continued in the regression model. Statistical analyses were carried 
out with the help of SPSS version 14 and MINITAB version 14 software. To illustrate this sample, in the results, one table will be displayed with the SF-36 scores of caregivers for children with cancer undergoing chemotherapy and of caregivers for healthy children, resulting from a study accomplished in Uberlândia(10), beesides scores for the Brazilian adult population, in comparison with our findings.

\section{Results}

The caregivers' average age was 35 years. Caregivers were mostly women $(87.5 \%)$ and married (75.0\%). Most of them had a low education level, up to finished primary education (71.9\%), did not receive help from other people for care (34.4\%), displayed some health problem $(21.9 \%)$ and took routine medication $(15.6 \%)$, Table 1 .

Table 1 - Socio-demographic characteristics of caregivers and children/adolescents with cancer undergoing chemotherapy. Cuiabá, MT, Brazil, 2008

\begin{tabular}{|c|c|}
\hline Caregiver characteristics & $n=32$ \\
\hline Age: (years) & $35(23-47)$ \\
\hline \multicolumn{2}{|l|}{ Gender: } \\
\hline Female & $28(87.5 \%)$ \\
\hline Male & $4(12.5 \%)$ \\
\hline \multicolumn{2}{|l|}{ Marital status } \\
\hline Married & $24(75.0 \%)$ \\
\hline Divorced/widowed & $4(12.4 \%)$ \\
\hline Single & $4(12.5 \%)$ \\
\hline \multicolumn{2}{|l|}{ Skin color: } \\
\hline White & $15(46.9 \%)$ \\
\hline Mulatto & $12(37.5 \%)$ \\
\hline Black & $5(15.6 \%)$ \\
\hline \multicolumn{2}{|l|}{ Instruction level } \\
\hline Unfinished primary & $4(12.5 \%)$ \\
\hline Finished primary & $19(59.4 \%)$ \\
\hline Secondary & $6(18.7 \%)$ \\
\hline Higher & $3(9.4 \%)$ \\
\hline \multicolumn{2}{|l|}{ Received help to take care of the child } \\
\hline No & $11(34.4 \%)$ \\
\hline YesS & $21(65.6 \%)$ \\
\hline \multicolumn{2}{|l|}{ Employment situation } \\
\hline Housewife & $21(65.6 \%)$ \\
\hline Employed & $5(15.6 \%)$ \\
\hline Autonomous & $3(9.4 \%)$ \\
\hline Unemployed & $3(9.4 \%)$ \\
\hline \multicolumn{2}{|l|}{ Absent from work to take care of the child } \\
\hline No & $28(87.5 \%)$ \\
\hline Yes & $4(12.5 \%)$ \\
\hline \multicolumn{2}{|l|}{ Any health problem } \\
\hline No & $25(78.1 \%)$ \\
\hline \multirow[t]{2}{*}{ Yes } & $7(21.9 \%)$ \\
\hline & ntinuation. \\
\hline
\end{tabular}

Table 1 - (continuation)

\begin{tabular}{lc}
\hline \multicolumn{1}{c}{ Caregiver characteristics } & $\mathbf{n = 3 2}$ \\
\hline Which health problem & $25(78.1 \%)$ \\
None & $4(12.5 \%)$ \\
Others & $3(9.4 \%)$ \\
Arterial hypertension & \\
Takes routine medication & $27(84.4 \%)$ \\
No & $5(15.6 \%)$ \\
Yes & \\
Consulted a physician in the last year & $12(37.5 \%)$ \\
0 & $7(21.9 \%)$ \\
1 & $9(28.1 \%)$ \\
2 & $4(12.5 \%)$ \\
$\geq 3$ & $8,3(0-20)$ \\
Time married (years) & $2,7(1-8)$ \\
Number of children & $16,1(3-54)$ \\
Time as caregiver (in months) & \\
& $\mathbf{n}=32$ \\
\hline \multicolumn{1}{c}{ Child/adolescent characteristics } & $8,62(2-17)$ \\
\hline Age (years): & $15(46,9 \%)$ \\
Gender & $17(53,1 \%)$ \\
Male & \\
Female & $18(58.1 \%)$ \\
Diagnosis & $4(12.9 \%)$ \\
Leukemias & $10(29.0 \%)$ \\
Others &
\end{tabular}

Scores expressed as averages ( \pm SD) and percentages.

The 32 caregivers' average dimension scores on the Caregiver Burden Scale (CBS) are displayed in Table 2 and the most compromised dimensions were: isolation (2.26), environment (2.12) and disappointment (2.04).

Table 2 - Partial and total caregiver burden scores according to CBS of caregivers for children/adolescents with cancer undergoing chemotherapy. Cuiabá, MT, Brasil, 2008

\begin{tabular}{lc}
\hline \multicolumn{1}{c}{ Burden dimensions } & Mean \pm Standard Error \\
\hline General Tension & $1.93 \pm 0.13$ \\
Isolation & $2.26 \pm 0.17$ \\
Disappointment & $2.04 \pm 0.12$ \\
Emotional involvement & $1.35 \pm 0.10$ \\
Environment & $2.12 \pm 0.14$ \\
General average & $1.94 \pm 0.09$ \\
\hline
\end{tabular}

$\mathrm{CBS}=$ Cargiver Burden Scale

Data in Table 3 compare the average score in each SF-36 dimension for the caregivers in this study with scores of other caregivers to children and adolescents with cancer treated in Uberlândia-MG and with the control group of caregivers to normal children in the same study, and also with data for the Brazilian normal population. 
Table 3 - Mean SF-36 scores of caregivers in this study, caregivers to children undergoing chemotherapy in Uberlândia, caregivers to normal children in Uberlândia and Brazilian normal population data

\begin{tabular}{lcccc}
\hline \multicolumn{1}{c}{ SF-36 Dimensions } & Caregivers in this Study & Caregivers from Uberlândia* & Control group Uberlândia* $^{*}$ & ${\text { Brazilian population }{ }^{\dagger}}^{*}$ \\
\hline Physical functioning & 83.0 & 85.0 & 90.0 & 83.0 \\
Physical role functioning & 71.1 & 75.0 & 100.0 & 87.0 \\
Bodily pain & 60.9 & 62.0 & 72.0 & 73.0 \\
General health perception & 68.3 & 77.0 & 87.0 & 75.0 \\
Vitality & 60.0 & 60.0 & 75.0 & 70.0 \\
Social role functioning & 79.4 & 75.0 & 100.0 & 84.0 \\
Emotional role functioning & 59.3 & 66.7 & 100.0 & 86.0 \\
Mental health & 74.2 & 45.2 & 76.0 & 73.0 \\
\hline
\end{tabular}

SF-36 ("Medical Outcomes Study - 36 item Short- From Survey").

*Cunha CM. Avaliação transversal da qualidade de vida de cuidadores de crianças e adolescentes com câncer por meio de um instrumento genérico-"36 item short form health survey questionnaire (SF-36) [thesis]. Universidade Federal de Uberlândia-MG; 2007(10).

+ Diniz A. Qualidade de vida de pacientes com HIV positivo e indivíduos com risco para infecção pelo HIV [thesis]. São Paulo: Universidade Federal de São Paulo; 2007.

According to the Beck Depression Inventory, 6.25\% of caregivers presented depression and $9.38 \%$ dysphoria, while $84.38 \%$ obtained normal scores. The BDI items that most contributed to the presence of depression were irritability, decreased libido, self-accusation and crying, and, to the presence of dysphoria were irritability, loss of interest in other people and sleep.
When correlating the SF-36 dimension scores with the caregivers' general burden and the Beck Depression Score, using Spearman's correlation coefficient $(\rho)$, a statistically significant correlation was observed between vitality and mental health and care burden, also observed between mental health and depression, as shown in Table 4.

Table 4 - Spearman's correlation coefficient between SF-36 dimension scores, general care burden score (CBS) and Beck Depression Inventory (BDI) of 32 caregivers to children/adolescents with cancer undergoing chemotherapy. Cuiabá, MT, Brazil, 2008

\begin{tabular}{|c|c|c|c|c|}
\hline SF36 Dimension & CBS Correlation & p & BDI Correlation & p \\
\hline Physical functioning & -0.289 & 0.109 & -0.017 & 0.928 \\
\hline Physical role functioning & -0.163 & 0.373 & 0.006 & 0.974 \\
\hline Bodily pain & -0.087 & 0.636 & 0.012 & 0.948 \\
\hline General health perception & -0.085 & 0.642 & -0.057 & 0.756 \\
\hline Vitality & -0.424 & 0.016 & -0.197 & 0.281 \\
\hline Social role functioning & -0.314 & 0.081 & -0.132 & 0.471 \\
\hline Emotional role functioning & -0.218 & 0.231 & -0.306 & 0.088 \\
\hline Mental health & -0.516 & 0.002 & -0.359 & 0.043 \\
\hline
\end{tabular}

SF-36 ("Medical Outcomes Study - 36 item Short- From Survey").

Data in Table 5 show the correlation among sociodemographic variables, caregivers' average burden and SF-36 dimension scores. The variables that most affected the caregiver's global burden were: mental health (25.55\%), spending on caregiver function (11.30\%) and pain $(4.5 \%)$.

Table 5 - Multiple linear regression analysis among general caregiver burden score, SF-36 dimensions and sociodemographic variables of 32 caregivers to children/adolescents with cancer undergoing chemotherapy. Cuiabá, MT, Brazil, 2008

\begin{tabular}{|c|c|c|c|}
\hline Variable & Coefficient & Standard deviation & $\mathbf{R}^{2}$ \\
\hline Mental health & -0.0181 & 0.0046 & 25.55 \\
\hline Spending on caregiver function & 0.45900 & 0.1887 & 11.30 \\
\hline Absence from work & -0.3726 & 0.2260 & 6.14 \\
\hline Pain & 0.0084 & 0.0038 & 4.50 \\
\hline Physical functioning & -0.0027 & 0.0019 & 2.91 \\
\hline
\end{tabular}

Obs: residual analysis was performed to check the adequacy of this model. After this analysis, the model was considered adequate, with $\beta_{0}=2.6455$ and the determination coefficient was $50.40 \%\left(R^{2}=50.40\right)$, with a standard deviation for the sample of $0.4151(\mathrm{~s}=0.4151), F_{5,26}=2.59$ and $\mathrm{p}=0.002(p=0.002)$. The general model explained $50.40 \%$ of the effect measured by the general caregiver burden. 


\section{Discussion}

The present study results permit a broad discussion on how the cancer diagnosis and treatment in children affect caregivers' lives. The caregivers' average age (35 years) bordered on the age demonstrated in different studies of caregivers to children with cancer(3,10-11), as well as caregivers to children with cerebral palsy ${ }^{(12)}$ and juvenila idiopathic arthritis(13).

The children's average age was 8.62 years, similar to the age range in other studies on children with cancer ${ }^{(10,14)}$. Brazilian data appoint leukemia as the most frequent child cancer, followed by lymphomas, and the target age between 1 and 4 years and between 15 and 18 years, respectively. The age range classification for child cancer, in most studies, considers ages between 0 and 18 years incomplete, with the Brazilian average age ranging between 8 and 10 years $^{(15)}$. As for the children's gender, incidence levels were higher among boys, similar to literature data(16).

Among caregivers, women predominated, specifically the mother, compatible with other studies, in which female caregivers exceeded $70 \%(10,12)$. In general, the mother believes that "nobody can rise up to her to take care, protect and see to her child's needs"(1). Most caregivers $(79.7 \%)$ were married/had a fixed partner - lower than for caregivers of children with juvenile idiopathic arthritis $(92.5 \%)^{(13)}$ and children with brain tumor $(93.3 \%)^{(14)}$. This lower rate can be due to the fact that, according to the Brazilian Institute of Geography and Statistics, the number of separations and divorces has been increasing in Brazil: in 2007, for every four weddings, one dissolution was registered(17).

In this study, despite most caregivers' low education level, no correlation was found between that variable and QoL or burden. The same was true in another study involving caregivers to children with cancer which also used the SF-36(10). The research accomplished in the Netherlands, however, among caregivers to children with falciform anemia showed that the low education level was significantly associated with lower motor function and pain scores ${ }^{(18)}$.

As for employment, $65.6 \%$ did housework and $9.4 \%$ were unemployed, totaling $74.0 \%$ of caregivers without monthly income. Studies demonstrate that, when one of the children has cancer, employment contracts are broken due to the need for organization for child care and treatment, compromising family income ${ }^{(4)}$; many caregivers end up losing their job after the diagnosis(11), due to the difficulty to reconcile care and work activities ${ }^{(1)}$. Based on these data, the report on the caregivers' lack of need to remain absent from work is understandable ( $87.5 \%)$, as most informed they were housewives or unemployed. Despite the distancing mentioned in literature between other family members and the caregiver(4), caregivers also develop other activities, as most of them have other children, like in the present study with an average 2.7 children. Also, $34.4 \%$ of caregivers did not receive help to take care of the sick child or see to treatment demands (resources, including time and money).

Research results show that the fact that they do not have anyone to share care and housework with make most caregivers lose their job ${ }^{(9)}$. Parent of children with cancer are obliged to deliver care to their children day and night, which has influenced the time left to see to their own needs ${ }^{(19)}$. In the present study, the mean time of care for the child exceeded one year (16.1 months). The prolonged care time also increases the commitment of QoL and the care burden ${ }^{(6,20)}$.

In this study, $21.9 \%$ of caregivers mentioned some health problem, $15.6 \%$ took medication regularly and $62.5 \%$ had sought medical care at least once in the last year. Although the population comprised young adults, they reported chronic illness problems, which is not frequent for this age range ${ }^{(10)}$; a study demonstrated that up to $41 \%$ of caregivers to children with cancer ended up getting ill at some time during treatment ${ }^{(11)}$.

The average general caregiver burden, measured through the CBS, corresponded to 1.94. Few studies assess the burden for caregivers to children with chronic illnesses through scales. These studies are normally qualitative or used questionnaires structured specifically for the study(1,11,19). A study that assessed the burden for caregivers to children with cerebral palsy, using the Burden Interview (BI) scale, identified that the low socioeconomic level and the child's level of motor commitment were the variables that most interfered negatively in the increase in caregivers' burden ${ }^{(12)}$. A study involving caregivers to young epilepsy patients using the Burden Interview Zarit and the SF-36 found a negative and statistically significant correlation among: general perceived health, mental health and emotional role functioning in the SF-36 and the caregiver burden(7). In the present study, a greater caregiver burden was observed in the following domains: isolation, environment and disappointment, although the change in each burden domain was not assessed separately. Some characteristics of the caregiver sample may have influenced these changes through, such as: a majority 
did not go out to work, some did not receive help to take care of the child, most caregivers were women and presented more depression signs, low education level, prolonged care delivery time to sick children and commitment of several quality of life dimensions. These suppositions need further research though.

An earlier study involving caregivers to children with cancer undergoing chemotherapy and a control group, in Uberlândia-MG(10), found Six SF-36 scores in caregivers higher than the present findings, one lower and one equal score. The control group showed higher scores than the present in all domains. The findings were also similar to a study involving mothers to children with leukemia and a control group in Japan, which appointed lower scores on all SF-36 domains than in the control group, with statistically significant results in 5 out of 8 domains: physical role functioning, general perceived health, vitality, emotional role functioning and mental health ${ }^{(20)}$.

We also found caregivers with depression symptoms (2) and dysphoria symptoms (3), totaling $15.63 \%$. These findings are important because the mental changes the caregivers present can alter the quality of care they deliver to the children, besides personal harm. It should be highlighted that the BDI measures depression symptoms but does not diagnose depression. A study involving caregivers to children with cancer, using the BDI and SF-36, showed a moderate and significant correlation in all domains of the SF-36 mental component and the BDI. Only the social role functioning domain showed a weak but significant correlation ${ }^{(10)}$, reinforcing the information that a child's illness can affect the family relation.

Our findings regarding the existing correlation between the caregiver's average burden, the BDI and the SF-36 are similar to findings of researchers who looked at symptoms/disorders in mothers to children recently diagnosed with cancer regarding their adjustment trajectory and concluded that symptoms/disorders are common among parents to children with cancer during treatment, and that psychosocial interventions should be used to enhance parents and children's long-term wellbeing(21). In addition, other authors affirm that post-traumatic stress symptoms should be monitored by a multidisciplinary team, as this type of care favors patients and families ${ }^{(3,22)}$.

The multiple linear regression analysis performed in this study showed that the following variables were responsible for $50.4 \%$ of the care burden the caregivers experienced: mental health, bodily pain and physical role functioning in the SF-36, extra spending as caregivers and being obliged to stay away from work to see to the child's needs and treatment demands. Although the latter variable affected the minority of caregivers, it was significant for the burden of those who worked. It should be highlighted that mental health alone was responsible for $25.55 \%$ of this burden. In literature, no studies were found involving caregivers to children with cancer or even other chronic illnesses that used the SF-36 and CBS simultaneously. A study involving caregivers to adult patients submitted to hemodialysis, however, using the same instruments (CBS and SF-36), despite the difference in average age from caregivers in this study (46.1 versus 35.0 years, respectively), observed that mental health was also the domain that most collaborated with the care burden $(24.0 \%)^{(8)}$.

\section{Conclusion}

In view of the results, a great challenge exists to be explored in the caregiver/health team interaction regarding the caregiver's insertion in care delivery to children and caregivers' activities involving children can interfere in treatment success. Caregivers need interventions that enhance their physical, social and emotional wellbeing, with a view to a possible reduction in their care burden and the maintenance of their QoL. New research involving caregivers to children with cancer are needed with a view to further clarifications about this population and to support prevention and QoL enhancement measures.

Based on the present study results, caregivers to children with cancer undergoing chemotherapy present a care burden, demonstrated by the negative influence on CBS scores: isolation, environment and general tension, besides the general score. The caregivers' QoL showed to be significantly lower in the following SF-36 domains: emotional role functioning, vitality and pain.

A negative and statistically significant correlation was found between the general care burden score and the BDI results and between the burden and the mental health and vitality domains of the SF-36. About $50 \%$ of the burden caregivers to children with cancer undergoing chemotherapy experienced is explained by alterations in the caregiver's mental health, physical functioning and bodily pain; by the need to stay away from work and additional spending due to the caregiver's activity.

Although there is a referral center for child cancer treatment in Cuiabá, the number of caregivers in the study sample was small, based on which further similar studies are needed at other Brazilian services. 


\section{References}

1. Beck ARM, Lopes MH . Tensão devido ao papel de cuidador entre cuidadores de criança com câncer. Rev Bras Enferm. 2007;60(5):513-8.

2. Nascimento LC, Rocha SM, Hayres VH, Lima RAG. Crianças com câncer e suas famílias. Rev Esc Enferm USP. 2005;39(4):469-74.

3. Kazak AE, Boeving CA, Alderfer MA, Hwang WT, Reilly A. Posttraumatic stress symptoms during treatment in parents of children with câncer. J Clin Oncol. 2005;23(30):7405- 10.

4. Ortiz MCA, Lima RAG. Experiências de familiares de crianças e adolescentes, após o término do tratamento contra o câncer: subsídios para o cuidado de enfermagem. Rev. Latino-Am. Enfermagem. 2007;15(3):411-7.

5. Moreira PL, Angelo M. Tornar-se mãe de criança com câncer: construindo a parentalidade. Rev. Latino-Am. Enfermagem. 2008; 16(3):355-61.

6. Rhee YS, Yun YH, Park S, Shin DO, Lee KM, Yoo HJ, et al. Depression in family caregivers of cancer patients: the feeling of burden as a predictor of depression. J Clin Oncol. 2008;26(36):5890-5.

7. Westphal AC, Alonso NB, Silva TI, Azevedo AM, Caboclo LOSF, Garzon E, et al. Comparação da Qualidade de Vida e Sobrecarga dos Cuidadores de Pacientes com Epilepsia por Esclerose Mesial Temporal e Epilepsia Mioclônica Juvenil. J Epilepsy Clin Neurophysiol. 2005;11(2):71-6.

8. Belasco AG, Barbosa D, Bettencourt AR, Diccini $S$, Sesso R. Quality of life of family caregivers of elderly patients on hemodialysis and peritoneal dialysis. Am J Kidney Dis. 2006;48(6):955-63.

9. Gorestein C, Andrade L. Inventário de depressão de Beck: propriedades psicométricas da versão em português. Rev Psiq Clin. 1998;25(5 ed esp):245-50.

10. Cunha CM. Avaliação Transversal da Qualidade de Vida de Cuidadores de Crianças e Adolescentes com Câncer por meio de um instrumento genérico-"36 item short form health survey questionnaire" (SF-36). [dissertação de mestrado]. Uberlândia (MG): Universidade Federal de Uberlândia; 2007. 101 p.

11. Pereira MS, Magni RHH, Mingione ICD, Caran EMM. Os desafios diários do cuidador de crianças e de adolescentes com câncer. Prática Hosp. 2009;11(62):51-3.

12. Camargos ACR, Lacerda TTB, Viana SO, Pinto LRA, Fonseca MLS. Avaliação da sobrecarga do cuidador de crianças com paralisia cerebral através da escala Burden Interview. Rev Bras Saúde Matern Infantil. 2009;9(1):31-7.
13. Iwamoto $\mathrm{V}$, Santos $\mathrm{SH}$, Skare $\mathrm{TL}$, Spelling $\mathrm{PF}$. Evaluation of psychological stress in primary caregivers of patients with juvenile idiopathic arthritis. J Pediatr (RJ). 2008;84(1):91-4.

14. Chien LY, Lo LH, Chen CJ, Chen YC, Chiang CC, Yu Chao YM. Quality of life among primary caregivers of Taiwanese children with brain tumor. Cancer Nurs. 2003;26(4): 305-11.

15. Instituo Nacional de Câncer -SOBOPE (BR). Resultados comentários incidência por tipo de câncer. [acesso 3 maio 2010]. Disponível em http://www.inca. gov.br/tumores_infantis/2008.

16. Reis RS, Santos MO, Thuler LCS. Incidência de tumores pediátricos no Brasil. Rev Bras de Cancerol. 2007;53(1):55-5.

17. IBGE (BR) [acesso 3 maio 2010]. Disponível em: http://www.ibge.gov.br/home/presidencia/noticias/ noticiavisualiza.php?id_noticia $=1278 \&$ id_pagina $=1$

18. Tweel XW van den, Hatzmann J, Ensink E, Lee JH van der, Peters M, Fijnvandraat K, et al. Quality of life of female caregivers of children with sickle cell disease: a survey. Haematologica. 2008;93(4):588-93.

19. Pedro ENR, Funghetto SS. Concepções de cuidado para os cuidadores: um estudo com a criança hospitalizada com câncer. Rev Gaúch Enferm. 2005;26(2):210-9.

20. Yamazaki S, Sokejima S, Mizoue T, Eboshida A, Fukuhara $S$. Health-related quality of life of mothers of children with leukemia in Japan. Qual Life Res. 2005;14(4):1079-85.

21. Klassen AF, Klassen R, Dix D, Pritchard S, Yanofsky $\mathrm{R}, \mathrm{O}$ 'Donnell $\mathrm{M}$, et al. Impact of caring for a child with cancer on parent's heath-related quality of life. J Clin Oncol. 2008;26(36):5884-9.

22. Dolgin MJ, Phipps S, Fairclough DL, Sahler OJZ, Askins M, Noll RB, et al. Trajectories of adjustment in mothers of children with newly diagnosed cancer: A natural history investigation. J Pediatr Psychol. 2007;32(7):771-82.

Received: May. $18^{\text {th }} 2010$ Accepted: Apr. $4^{\text {th }} 2011$ 